\title{
INFLUENCE OF SEGMENTATION ON THE PRECISION OF CIRCUIT BASED METHODS
}

\section{Andrijana Kuhar, Vesna Arnautovski-Toševa, Lidija Ololoska-Gagoska, Leonid Grčev, Blagoja Markovski}

\author{
Faculty of Electrical Engineering and Information Technologies, \\ "Ss. Cyril and Methodius" University in Skopje, \\ Rugjer Bošković bb, P.O. box 574, 1001 Skopje, Republic of Macedonia \\ kuhar@feit.ukim.edu.mk
}

\begin{abstract}
A b s t r a c t: Numerical methods are based on segmenting the domain of calculations. In this paper the influence of wire segmentation on the precision of calculations of approximate numerical models for analysis of grounding systems is investigated. It is well known that increasing the number of segments leads to increased precision in the calculations. However, the maximum number of segments is limited by the conditions from the thin wire approximation that is implemented by these methods. As a result convergence of the numerical technique may not always be reached. In this paper convergence of the relative error obtained by each numerical method as a function of relative segment length is parametrically investigated.
\end{abstract}

Key words: segmentation; numerical models; convergence

\section{ВЛИЈАНИЕ НА СЕГМЕНТАЦИЈАТА ВРЗ ПРЕЦИЗНОСТА НА МЕТОДИТЕ БАЗИРАНИ НА ЕЛЕКТРИЧНИ КОЛА}

\begin{abstract}
А п с т р а к т: Нумеричките методи се базираат на сегментација на доменот во кој се вршат пресметките. Во овој труд е испитано влијанието на сегментацијата на спроводниците врз прецизноста на апроксимативните нумерички методи за анализа на заземјувачки системи. Познато е дека зголемувањето на бројот на сегменти доведува до зголемена прецизност на пресметките. Но максималниот број на сегменти е ограничен од условите на апроксимацијата на тенка жица која е имплементирана во овие методи. Поради тоа ограничување, во некои случаи може да не се постигне конвергенција на нумеричката техника што е применета. Во овој труд параметриски е анализирана конвергенцијата на релативната грешка која се прави со секој од нумеричките методи во функција од релативната должина на сегментот.
\end{abstract}

Клучни зборови: сегментација; нумерички методи; конвергенција

\section{INTRODUCTION}

Numerical methods are based on segmenting the domain of calculations. In the field of grounding system analysis there is a plethora of widely used exact and approximate numerical methods. The most important approximate methods are based on representing each segment of the conductor by an equivalent circuit branch. Most circuit models implement approximate solutions of the so called Mixed Potential Integral Equation (MPIE), while the rigorous Electromagnetic Model (EM) [1] yields the most precise results by numerically solving the MPIE with fewest approximations. The EM implements numerical solution of the MPIE by the Method of Moments (MoM) [2]. In the scientific public it is recognized as a reference method in the field. 


\section{CIRCUIT BASED MODELS}

The most important approximate methods are based on creating equivalent circuit branches to represent each segment of the conductor. The electrode is divided in $N$ fictitious segments whose length $\Delta l$ has to be much larger that its radius $a(\Delta l>10 a$ is usually adequate) in order to maintain the conditions for the thin wire approximation.

\section{A) Lumped circuit model}

The basic principle of the lumped circuit ( $R-L$ $C)$ model is to represent the conductor as a whole by a circuit derived from its input impedance. According to [3] the high-frequency model for the impedance is an inductor $L$ in a series with a parallel combination of a capacitor $C$ and a resistor $R$. At low frequencies this model reduces to the static grounding resistance of the conductor $R$. The parameters describe the conductor as a single segment and therefore do not include the inductive, capacitive or conductive coupling between different parts of the conductor.

The values of the circuit elements for a vertical grounding rod with radius $a$ and length $\Lambda(\Lambda>>a)$, from [4].

$$
\begin{aligned}
& R_{v}=\frac{\rho}{2 \pi \Lambda}\left[\log \frac{4 \Lambda}{a}-1\right](\Omega), \\
& L_{v}=\frac{\mu_{0} \Lambda}{2 \pi}\left[\log \frac{4 \Lambda}{a}-1\right](\mathrm{H}),
\end{aligned}
$$

where $\rho$ is the specific resistivity of earth. The values of the circuit elements $[3,5]$ in the case of a horizontal grounding electrode buried in homogeneous earth at depth $d(\Lambda>>a, \Lambda>>d)$ are:

$$
\begin{aligned}
& R_{h}=\frac{\rho}{\pi \Lambda}\left[\log \frac{2 \Lambda}{\sqrt{2 a d}}-1\right](\Omega), \\
& L_{h}=\frac{\mu_{0} \Lambda}{2 \pi}\left[\log \frac{2 \Lambda}{a}-1\right](\mathrm{H}) .
\end{aligned}
$$

The value of the capacitor is calculated by

$$
C_{v, h}=\frac{\rho \varepsilon}{R_{v, h}}(\mathrm{~F}) .
$$

An evolved (and widely used [6 - 8]) version of the $R-L-C$ model is presented in Figure 1. Basically, it is a discrete approximation of a trans- mission line (TL) with parameters per length obtained from (1) - (3).

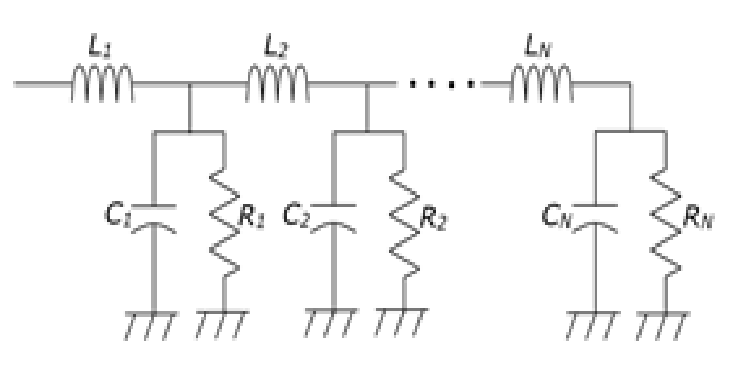

Fig. 1. $R-L-C$ circuit representation of a segmented conductor

The elements of the discrete $R-L-C$ section that represents each segment are defined by [3, 7]:

$$
R_{n}=\frac{R^{\prime} N}{\Lambda}, \quad C_{n}=\frac{C^{\prime} \Lambda}{N}, \quad L_{n}=\frac{L^{\prime} \Lambda}{N} .
$$

The primary TL parameters per length in (4) are obtained using (1) - (3), as in

$$
\begin{aligned}
R_{v, h}^{\prime} & =\frac{1}{G_{v, h}^{\prime}}=R_{v, h} \Lambda(\Omega \mathrm{m}), \\
C_{v, h}^{\prime} & =C_{v, h} / \Lambda(\mathrm{F} / \mathrm{m}), \\
L_{v, h}^{\prime} & =L_{v, h} / \Lambda(\mathrm{H} / \mathrm{m}) .
\end{aligned}
$$

\section{B) Circuit based models that include electromagnetic coupling}

\section{Circuit based method-CBM}

One of the most significant circuit based methods - CBM, was introduced in 1998 [9]. It is frequently used for analysis of grounding systems [10], [11], [12], [13] and [14]. Electromagnetic influence between segments is taken into account, but propagation effects on the EM fields are not considered in CBM.

The longitudinal impedance of each segment of a perfectly conducting wire is of inductive character expressed in CBM as

$$
L_{m n}=\int_{\Delta_{m}} \vec{t}_{m} \cdot \vec{t}_{n} \psi_{A}\left(l_{-}, l_{n} ; m\right) d l
$$

where $\Delta l_{m}$ is the length of the $m$-th segment, $t_{m}$ and $t_{n}$ are unit vectors parallel to the observed- and source segment, respectively. 
The transversal impedances of each segment, $Z^{L}{ }_{m, n}$ are derived via the influence of the leakage current exiting segment $n$, on segment $m$,

$$
Z_{m n}^{L}=\frac{1}{j \omega} \cdot \frac{1}{\Delta l_{m} \Delta l_{n}} \int_{\Delta l_{m}} \vec{t}_{m} \cdot \vec{t}_{n} \psi_{V}\left(l_{n}, l_{n} ; m\right) d l
$$

where $\Delta l_{n}$ is the length of the $n$-th (source) segment, The elements defined by (6) and (7) constitute an equivalent circuit branch that represents each segment of the conductor. The resulting circuit is solved via conventional nodal analysis to obtain the potentials of the nodes.

The form of $\psi_{A}$ and $\psi_{V}$ in (6) and (7) equals

$$
\begin{aligned}
& \psi_{A}\left(l_{n_{1}}, l_{n_{2}} ; m\right)=\int_{l_{n_{1}}}^{l_{n_{2}}} G_{A}(n, m) d l^{\prime}, \\
& \psi_{V}\left(l_{n_{1}}, l_{n_{2}} ; m\right)=\int_{l_{n_{1}}}^{l_{n_{2}}} G_{V}(n, m) d l^{\prime},
\end{aligned}
$$

where $G_{A}$ and $G_{V}$ are magnetic vector potential and electric scalar potential Green's functions for an unbounded medium:

$$
\begin{aligned}
& G_{A}\left(\vec{r}, \vec{r}^{\prime}\right)=\frac{\mu_{0}}{4 \pi} \frac{\exp \left(-j k_{1}\left|\vec{r}-\vec{r}^{\prime}\right|\right)}{\left|\vec{r}-\vec{r}^{\prime}\right|}, \\
& G_{V}\left(\vec{r}, \vec{r}^{\prime}\right)=\frac{1}{4 \pi \underline{\varepsilon}} \frac{\exp \left(-j k_{1}\left|\vec{r}-\vec{r}^{\prime}\right|\right)}{\left|\vec{r}-\vec{r}^{\prime}\right|}
\end{aligned}
$$

where $\underline{\varepsilon}=\varepsilon-\mathrm{j} \sigma / \omega$ is the complex permittivity of the medium and $\sigma=1 / \rho$.

The way to solving integrals in (6) and (7) within CBM is limited by the quasi-stationary approximation, i.e. only the first element of the Maclaurin series of $G_{A, V}$ is taken into account. All remaining elements of (9) are neglected, yielding

$$
\begin{aligned}
G_{A}\left(\vec{r}, \vec{r}^{\prime}\right) & =\frac{\mu_{0}}{4 \pi\left|\vec{r}-\vec{r}^{\prime}\right|}, \\
G_{V}\left(\vec{r}, \vec{r}^{\prime}\right) & =\frac{1}{4 \pi \varepsilon\left|\vec{r}-\vec{r}^{\prime}\right|} .
\end{aligned}
$$

Substituting (10) in (6) and (7) yields the same type of double integrals that have analytical solution for the usually implemented combinations of grounding conductors.
Traditional and modified image methods [15, 16] are implemented with CBM to take into account the influence of earth/air interface on the form of Green's functions.

\section{Hybrid electromagnetic model - HEM}

The hybrid electromagnetic model [17] is a dual approach in analysis of grounding systems - it combines numerical electromagnetic calculations with electric circuit theory. The hybrid electromagnetic model (HEM) is frequently used for analysis of grounding systems due to its precision [12-14] and [17-22].

Within HEM, the longitudinal and transversal impedances of an arbitrary segment $m$ are defined by (6) and (7), respectively.

Unlike the quasi-static forms in CBM, the Green's functions in the above mentioned expressions maintain the full-wave form. In this paper the following technique from [23] is implemented to approximate (8):

$$
\operatorname{Exp}\left(-j k_{1} r_{m n}\right) \int_{\Delta \mathrm{l}_{m}} \int_{\Delta \mathrm{l}_{n}} \frac{1}{\left|\vec{r}-\vec{r}^{\prime}\right|} d l d l^{\prime}
$$

where $r_{m n}$ is the distance between middle points of the source and segment of interest.

Up-to-date, authors have implemented the HEM method using the traditional and modified image methods $[15,16]$, as well as complex images [22], to take into account the presence of earth/air interface.

\section{RESULTS}

In this section, convergence of numerical calculations as a function of relative segment length is parametrically investigated. The segment length ratio - S.L.R, is calculated as a ratio of segment length vs. the length of the whole conductor. Thus, S.L.R. is inversely proportional to the number of segments, $N$ :

$$
\text { S.L.R. }=100 \cdot \frac{\Delta l}{\Lambda}(\%) . \quad(=1 / N)
$$

The horizontal grounding electrode, as one of the most frequently used types of grounding electrical systems is analyzed, presented in Figure 2. 


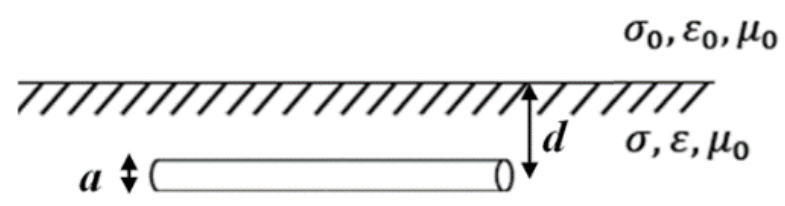

Fig. 2. Geometry of the analyzed case

The relative error in the impedance magnitude for the horizontal conductor is calculated by

$$
\Delta=\frac{|Z|-\left|Z^{R E F}\right|}{\left|Z^{R E F}\right|} \cdot 100(\%)
$$

where $Z$ is the magnitude of the impedance to ground calculated by implementation of HEM, CBM and the discrete $R-L-C$ model, and $Z^{R E F}$ is calculated by the rigorous EM method.

Tables 1, 2 and 3 present the value of S.L.R. at which the error converges in the calculations for a horizontal grounding conductor with length 4,10 and $40 \mathrm{~m}$, respectively, for several values of $\rho$ and $f$.

It is visible from Tables 1, 2 and 3 that, in general, for high frequencies lower number of segments is sufficient to reach convergence in the calculations.

Table 1

\begin{tabular}{|c|c|c|c|c|c|c|}
\hline \multirow[b]{3}{*}{$\begin{array}{l}\text { Frequency } \\
(\mathrm{Hz})\end{array}$} & \multicolumn{6}{|c|}{ Convergence value of S. L. R. (\%) } \\
\hline & \multicolumn{2}{|c|}{$\rho=50 \Omega \mathrm{m}$} & \multicolumn{2}{|c|}{$\rho=100 \Omega \mathrm{m}$} & \multicolumn{2}{|c|}{$\rho=500 \Omega \mathrm{m}$} \\
\hline & $\mathrm{CBM}$ & HEM & $\mathrm{CBM}$ & HEM & $\mathrm{CBM}$ & HEM \\
\hline $10^{3}$ & 12 & 12 & 13 & 13 & 11 & 11 \\
\hline $10^{6}$ & 25 & 25 & 35 & 35 & 10 & 10 \\
\hline $5 \cdot 10^{6}$ & 17 & 17 & 35 & 35 & 9 & 8 \\
\hline
\end{tabular}

Table 2

\begin{tabular}{ccccccc}
\multicolumn{8}{c}{10 m long conductor } \\
\hline \hline & $\rho=50 \Omega \mathrm{m}$ & $\rho=100 \Omega \mathrm{m}$ & $\rho=500 \Omega \mathrm{m}$ \\
\hline $\begin{array}{c}\text { Frequency } \\
(\mathrm{Hz})\end{array}$ & $\mathrm{CBM}$ & HEM & $\mathrm{CBM}$ & HEM & CBM & HEM \\
\hline $10^{3}$ & 6 & 6 & 7 & 7 & 5 & 5 \\
$10^{6}$ & 11 & 8 & 17 & 10 & 35 & 35 \\
$5 \cdot 10^{6}$ & 25 & 10 & 35 & 15 & 6 & 10 \\
\hline \hline
\end{tabular}

Table 3

\begin{tabular}{|c|c|c|c|c|c|c|}
\hline \multirow[b]{3}{*}{$\begin{array}{l}\text { Frequency } \\
(\mathrm{Hz})\end{array}$} & \multicolumn{6}{|c|}{ Convergence value of S. L. R. (\%) } \\
\hline & \multicolumn{2}{|c|}{$\rho=50 \Omega \mathrm{m}$} & \multicolumn{2}{|c|}{$\rho=100 \Omega \mathrm{m}$} & \multicolumn{2}{|c|}{$\rho=500 \Omega \mathrm{m}$} \\
\hline & $\mathrm{CBM}$ & HEM & $\mathrm{CBM}$ & HEM & $\mathrm{CBM}$ & HEM \\
\hline $10^{3}$ & 5 & 11 & 4 & 10 & 3 & 5 \\
\hline $10^{6}$ & 9 & 5 & 30 & 6 & 7 & 10 \\
\hline $5 \cdot 10^{6}$ & 9 & 5 & 17 & 6 & 17 & 12 \\
\hline
\end{tabular}

Figures 3, 4 and 5 show the relative error in the magnitude of the impedance to ground for earth with specific resistivity: $\rho=50 \Omega \mathrm{m}, \rho=100 \Omega \mathrm{m}$ and $\rho=500 \Omega \mathrm{m}$, respectively, as a function of S.L.R. (segment length ratio). The error is calculated by implementation of HEM, CBM, and the discrete $R$ $L-C$ method on a) $4 \mathrm{~m}$, b) $10 \mathrm{~m}$ and c) $40 \mathrm{~m}$ long horizontal grounding conductor, controlled by results obtained using the rigorous EM method [1]. The analyzed frequency in the presented cases is 1 $\mathrm{kHz}$. The relative error in the impedance magnitude at a frequency of $1 \mathrm{MHz}$ (which is considered high in the analysis of grounding conductors) obtained as a function of S.L.R. is presented in Figures 6, 7 and 8 , for earth with specific resistivity: $\rho=50 \Omega \mathrm{m}$, $\rho=100 \Omega \mathrm{m}$ and $\rho=500 \Omega \mathrm{m}$, respectively. The relative error in the impedance magnitude at a frequency of $5 \mathrm{MHz}$ (which is considered very high in the analysis of grounding conductors) obtained as a function of S.L.R. is presented in Figures 9, 10 and 11, for specific resistivity of earth: $\rho=50 \Omega \mathrm{m}, \rho$ $=100 \Omega \mathrm{m}$ and $\rho=500 \Omega \mathrm{m}$, respectively.

\section{DISCUSSION}

It is evident from Figures 3, 4 and 5 that for low frequencies $(1 \mathrm{kHz})$ the segmented $R-L-C$ model converges at large values of S.L.R. (small number of segments). At higher frequencies (1 MHz and $5 \mathrm{MHz}$, presented on Figures 6-11) this model yields extremely high relative error and does not converge for a sensible value of S.L.R. Because of this fact, it is not included in Tables 1, 2 and 3.

Regarding methods CBM and HEM, the relative error in the impedance magnitude at low frequency $(1 \mathrm{kHz})$ converges at S.L.R. $\sim 10$ (Figures 3, 4 and 5). In this case larger number of segments is required to reach convergence in the calculations.

It may be observed that at high frequencies (Figures 6-11) the convergence value of S.L.R. depends strongly on the value of $\rho$ for each investigated method. 
a)

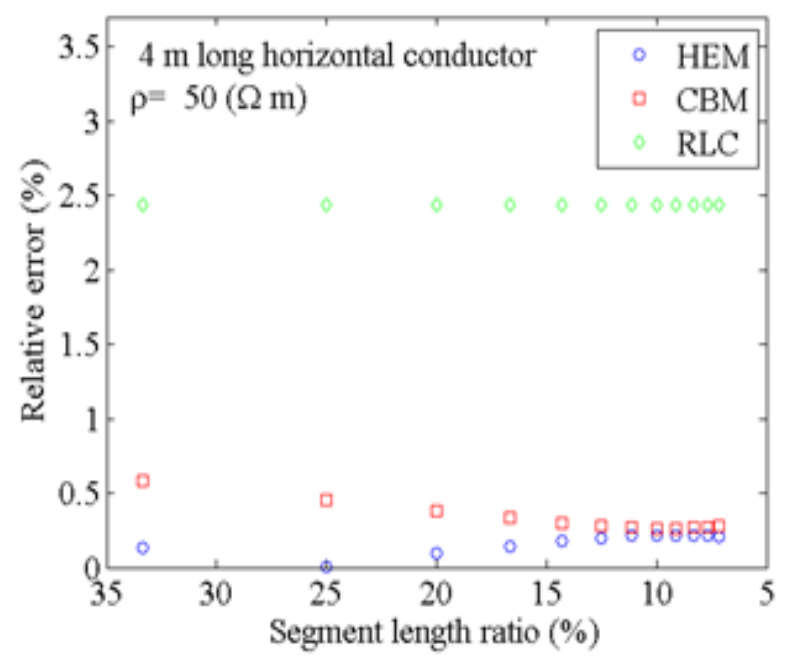

b)

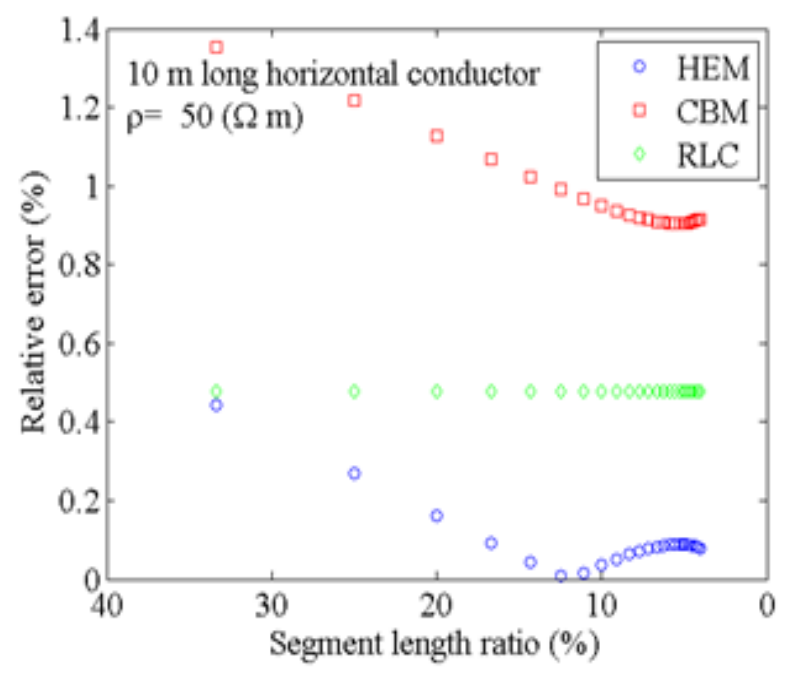

c)

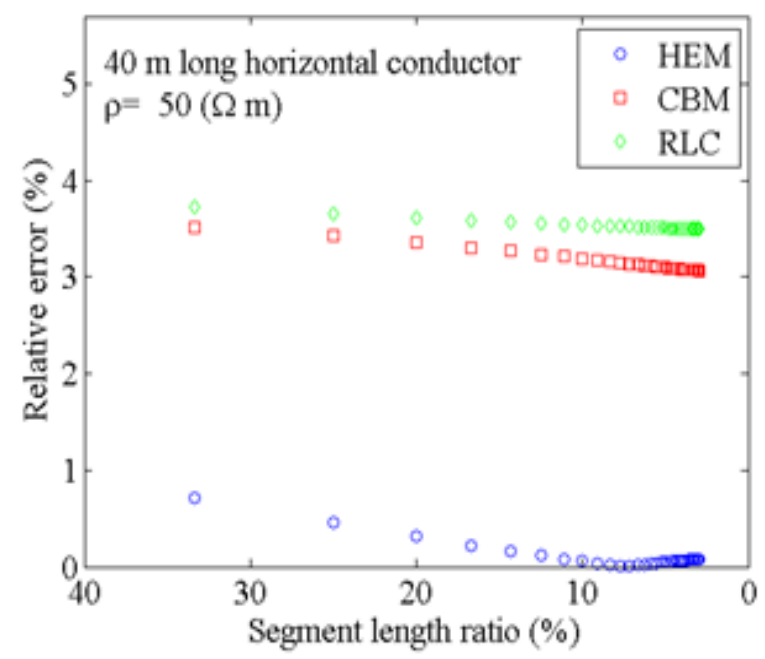

Fig. 3. Relative error in the impedance magnitude at $1 \mathrm{kHz}, \rho=50 \Omega \mathrm{m}$ a)

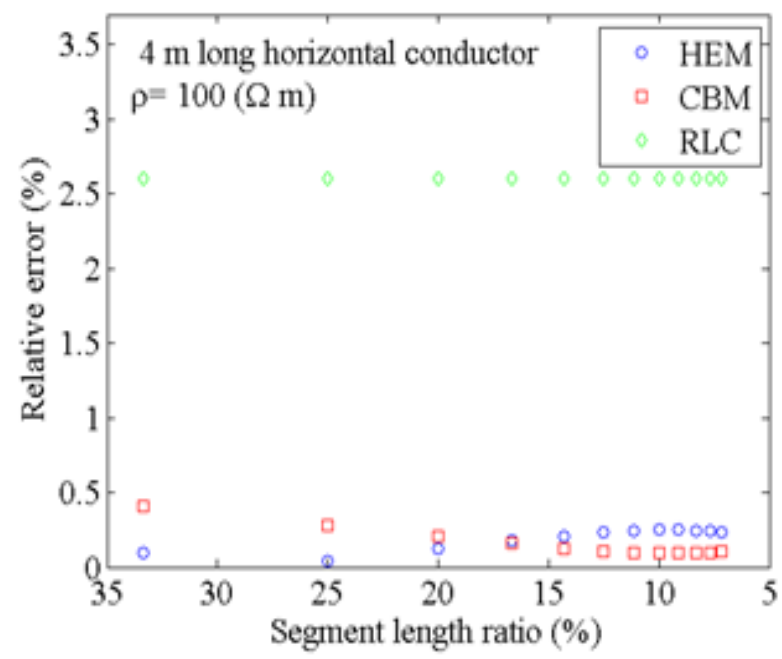

b)

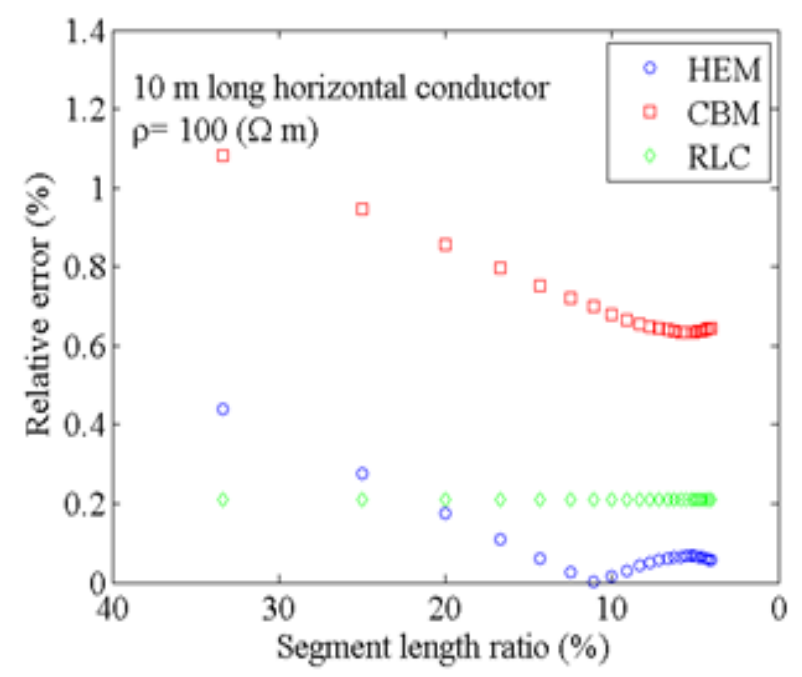

c)

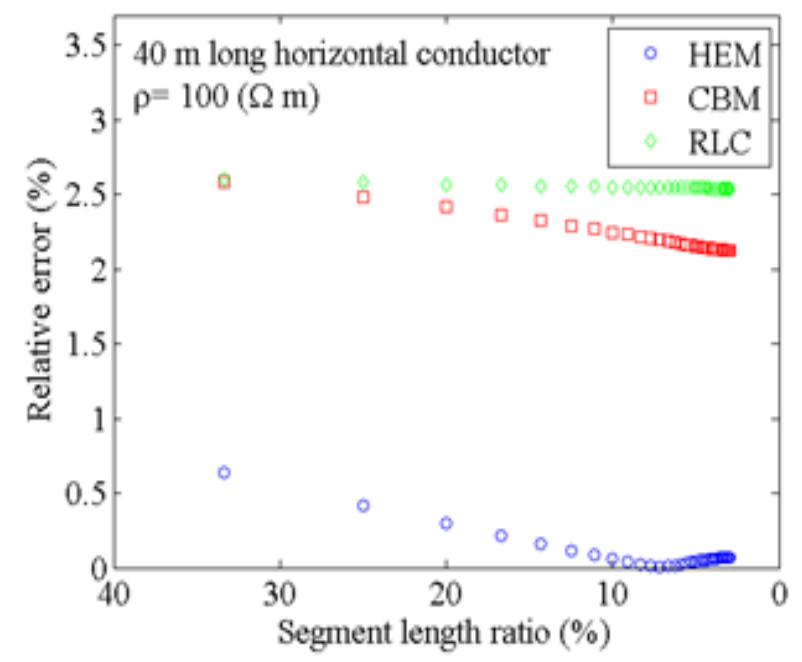

Fig. 4. Relative error in the impedance magnitude at $1 \mathrm{kHz}, \rho=100 \Omega \mathrm{m}$ 
a)

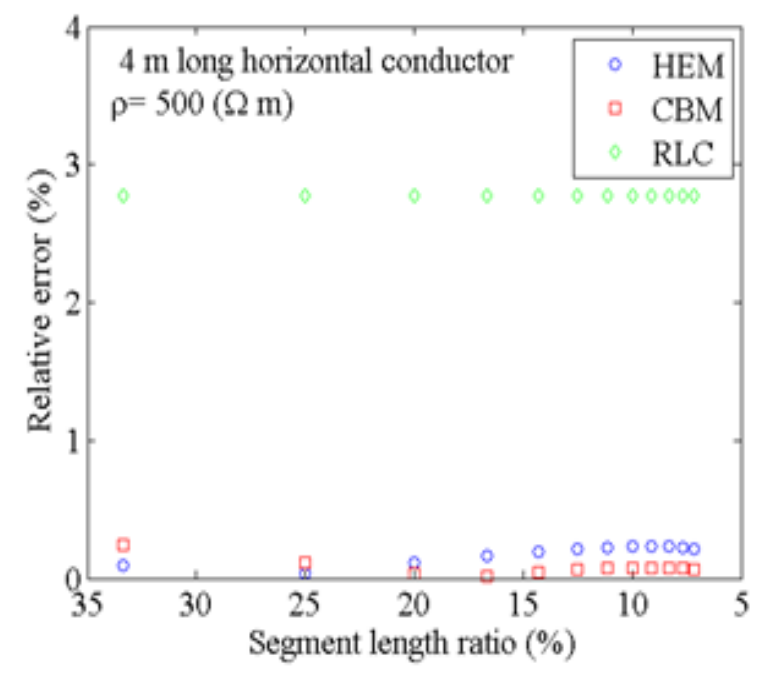

b)

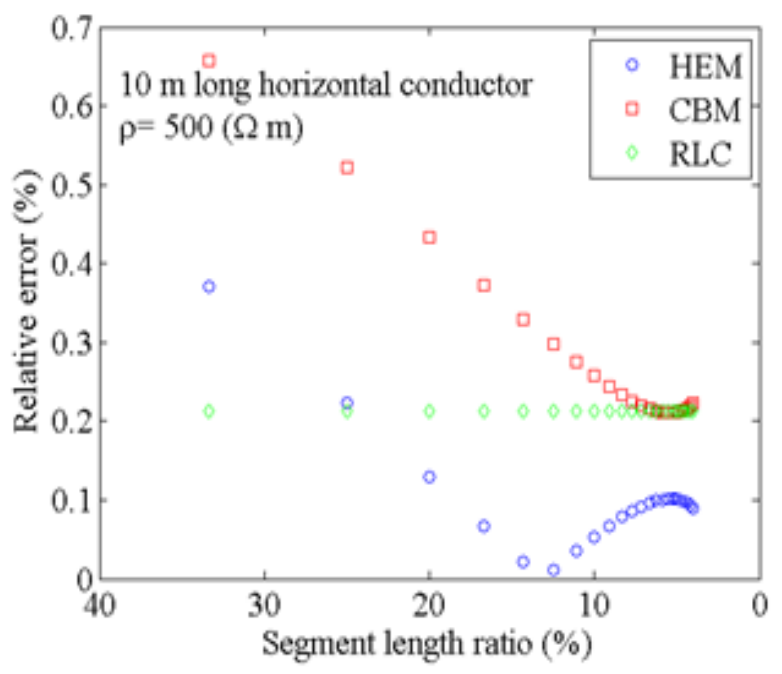

c)

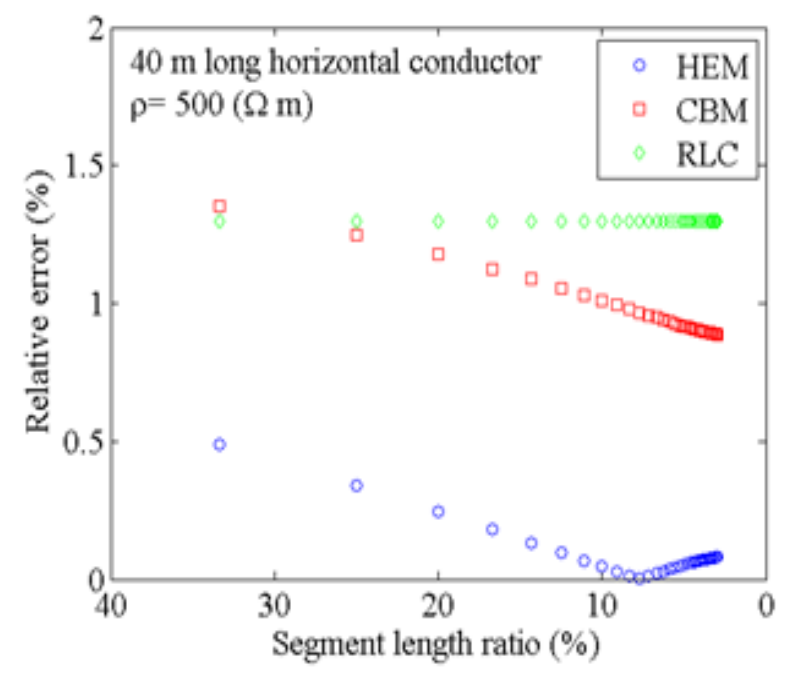

Fig. 5. Relative error in the impedance magnitude at $1 \mathrm{kHz}, \rho=500 \Omega \mathrm{m}$ a)

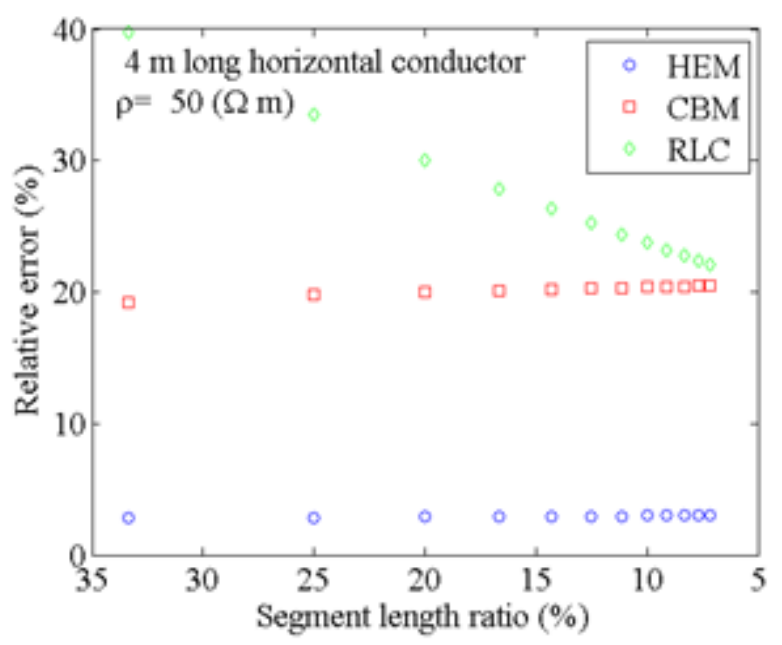

b)

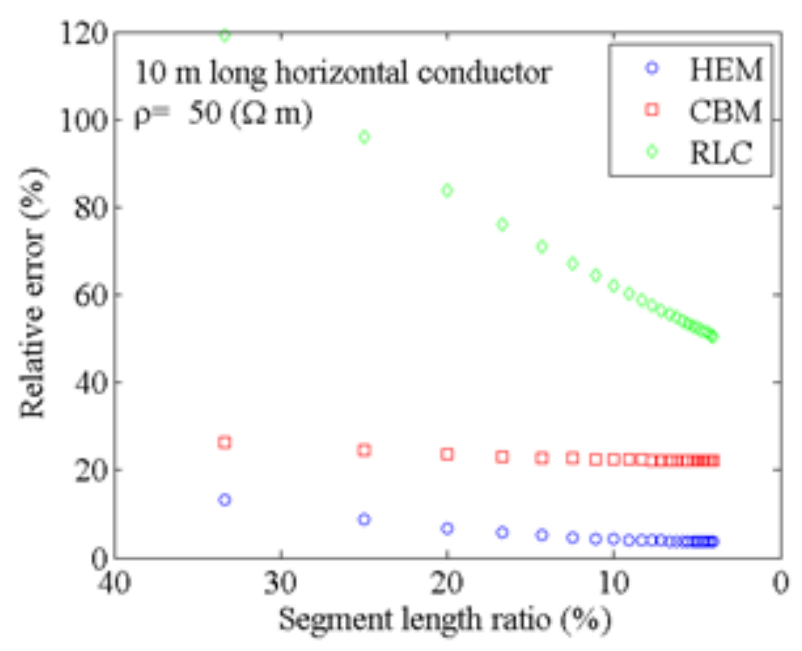

c)

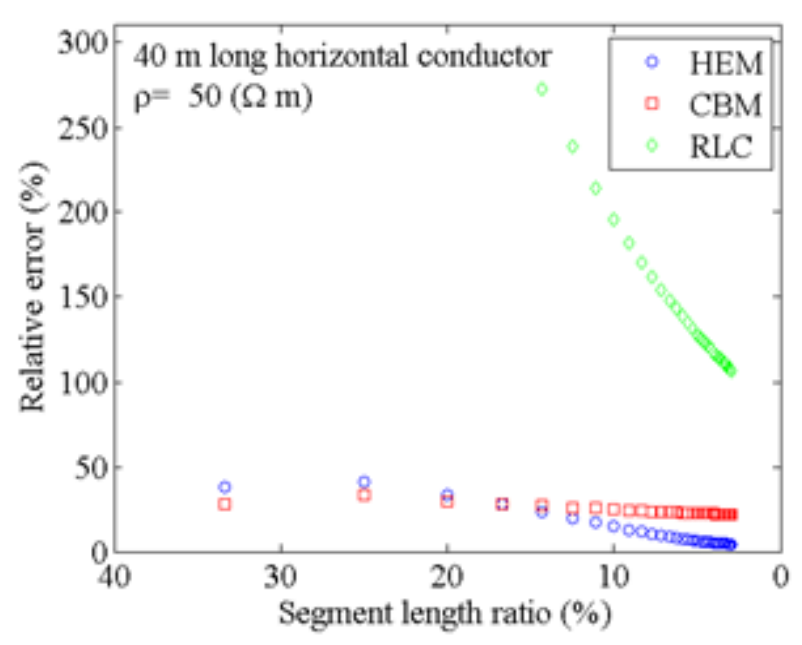

Fig. 6. Relative error in the impedance magnitude at $1 \mathrm{MHz}, \rho=50 \Omega \mathrm{m}$ 
a)

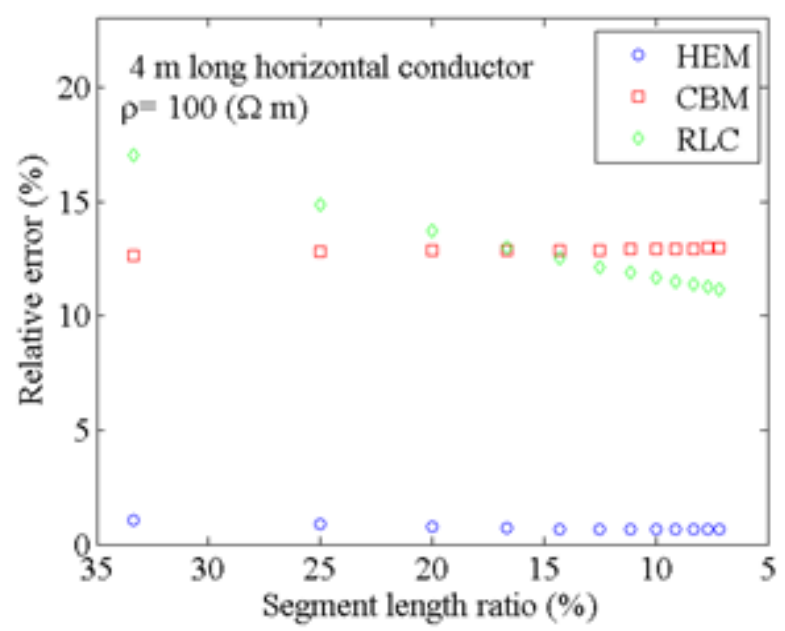

b)

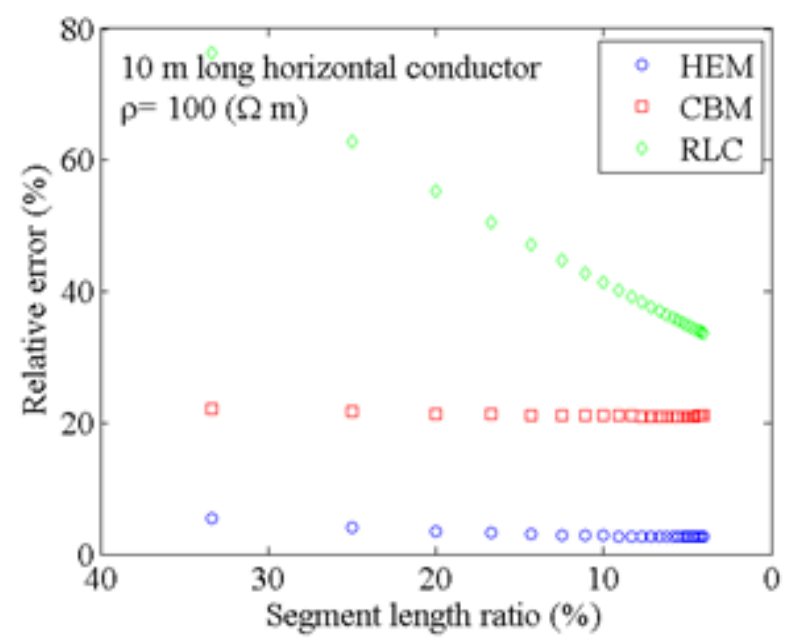

c)

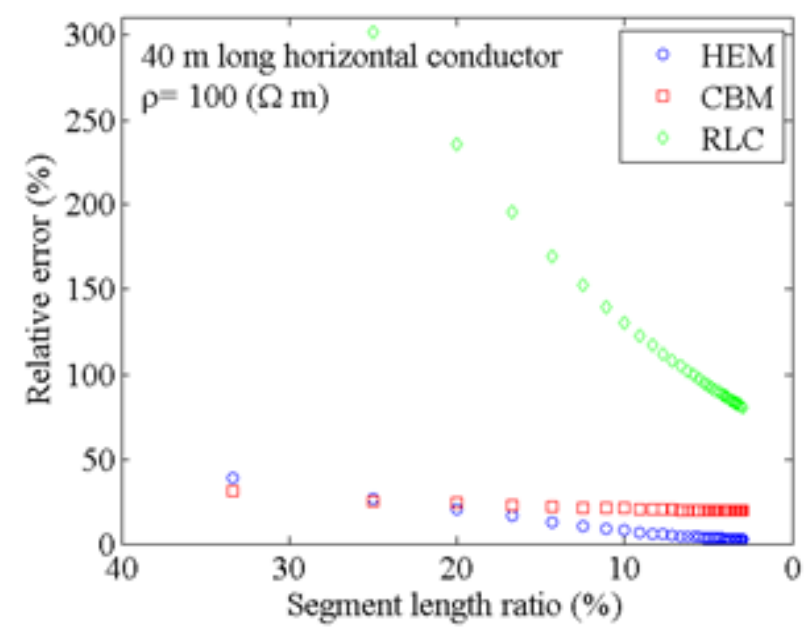

Fig. 7. Relative error in the impedance magnitude at $1 \mathrm{MHz}, \rho=100 \Omega \mathrm{m}$ a)

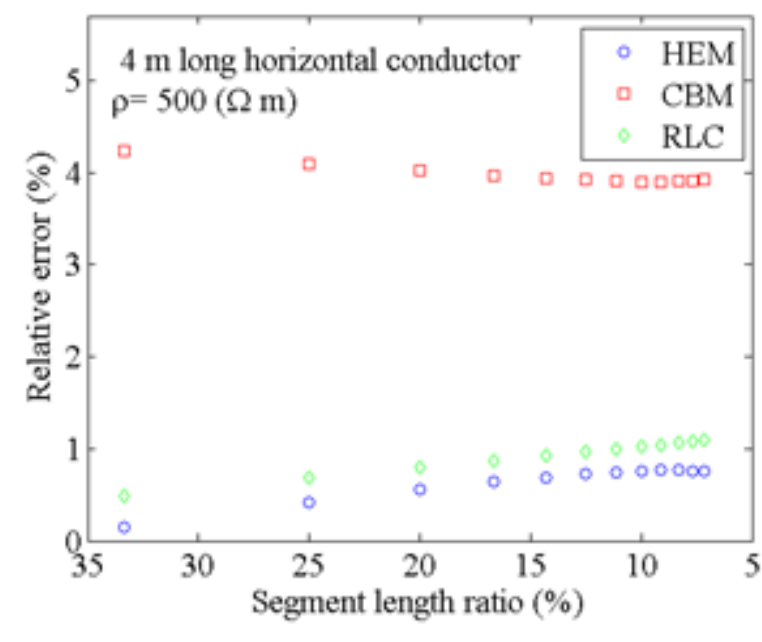

b)

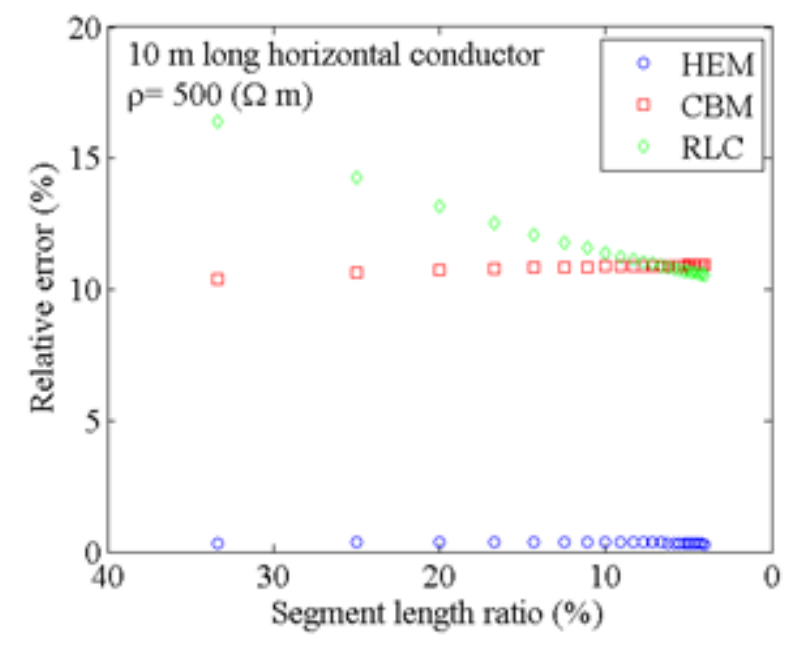

c)

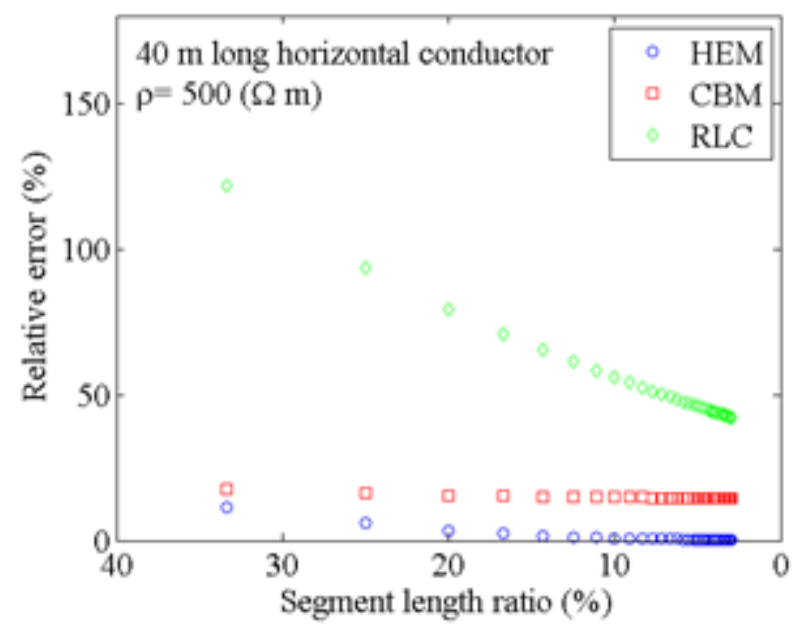

Fig. 8. Relative error in the impedance magnitude at $1 \mathrm{MHz}, \rho=500 \Omega \mathrm{m}$ 
a)

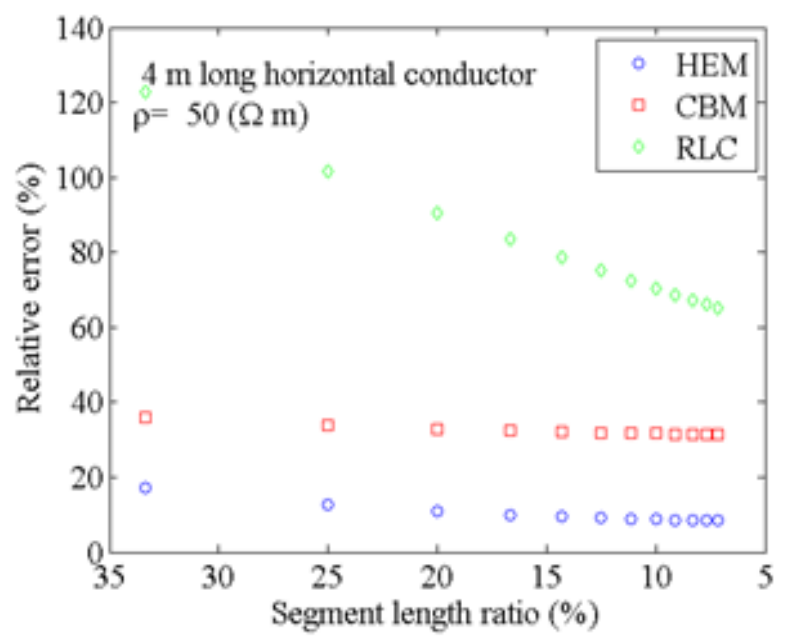

b)

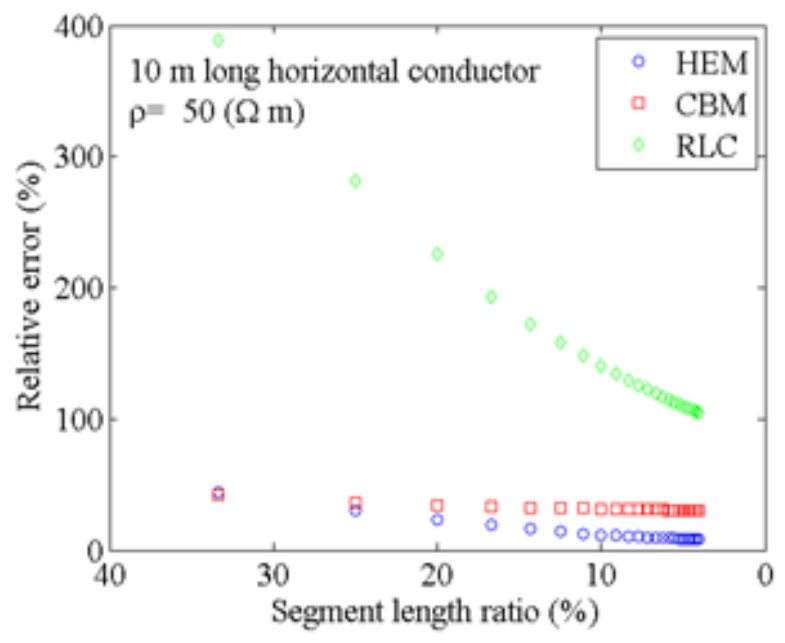

c)

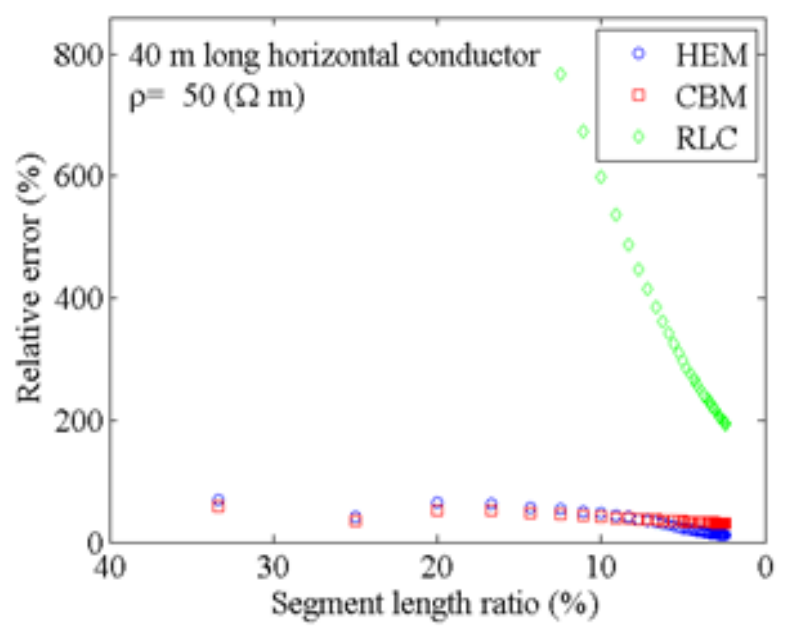

Fig. 9. Relative error in the impedance magnitude at $5 \mathrm{MHz}, \rho=50 \Omega \mathrm{m}$ a)

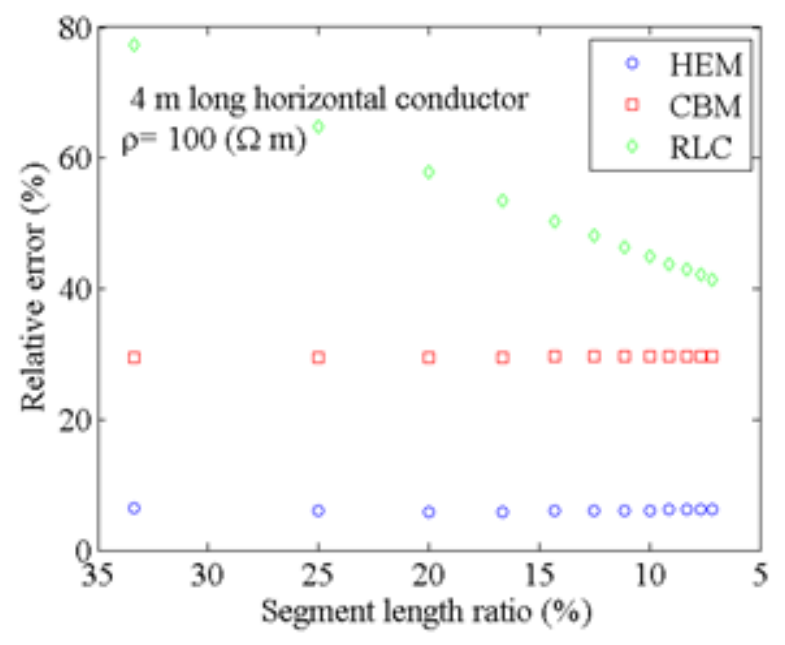

b)

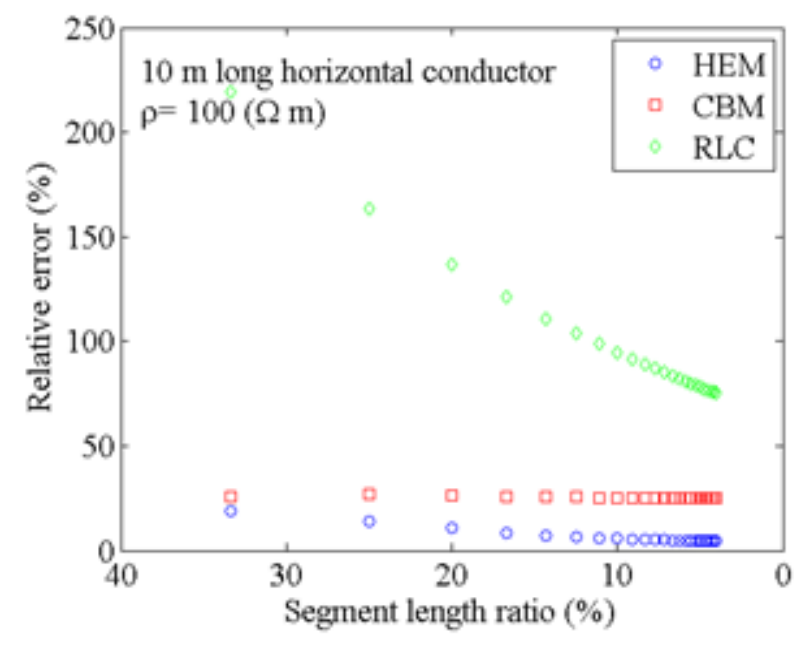

c)

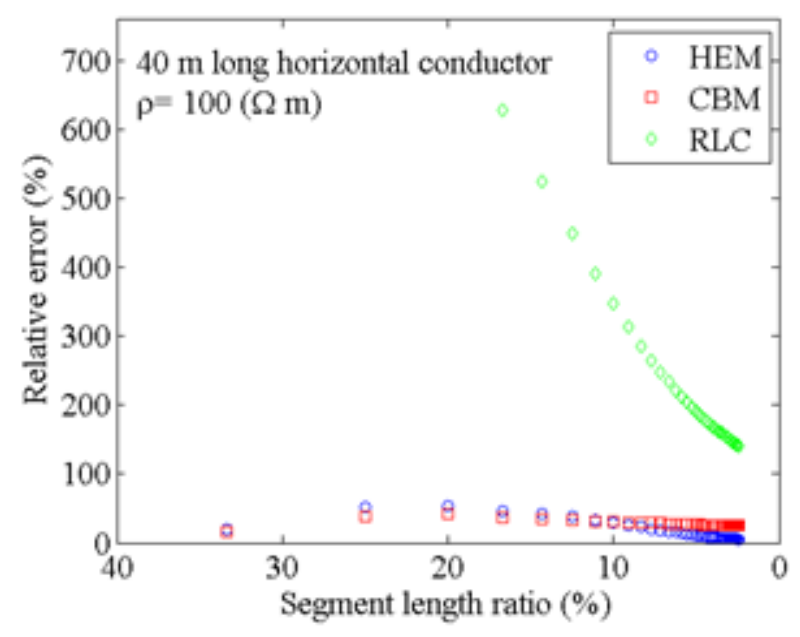

Fig. 10. Relative error in the impedance magnitude at $5 \mathrm{MHz}, \rho=100 \Omega \mathrm{m}$ 
a)

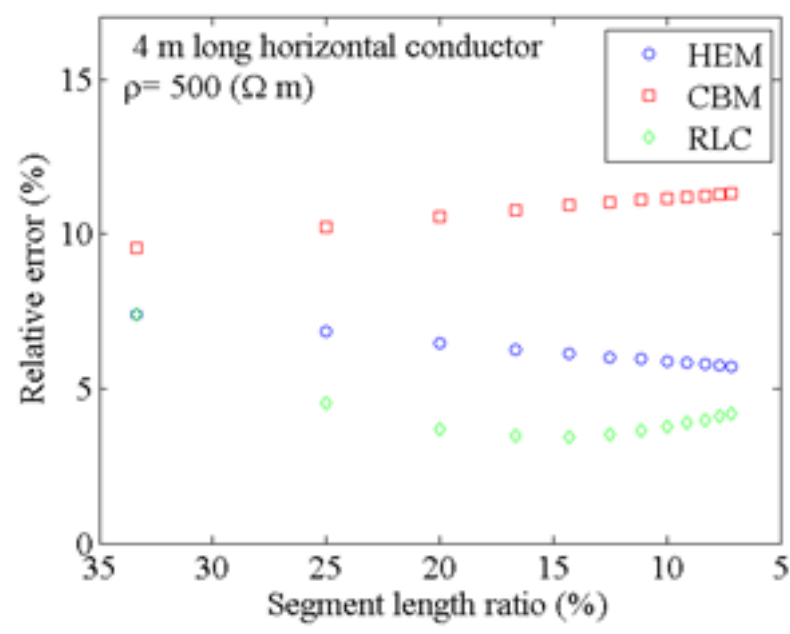

b)

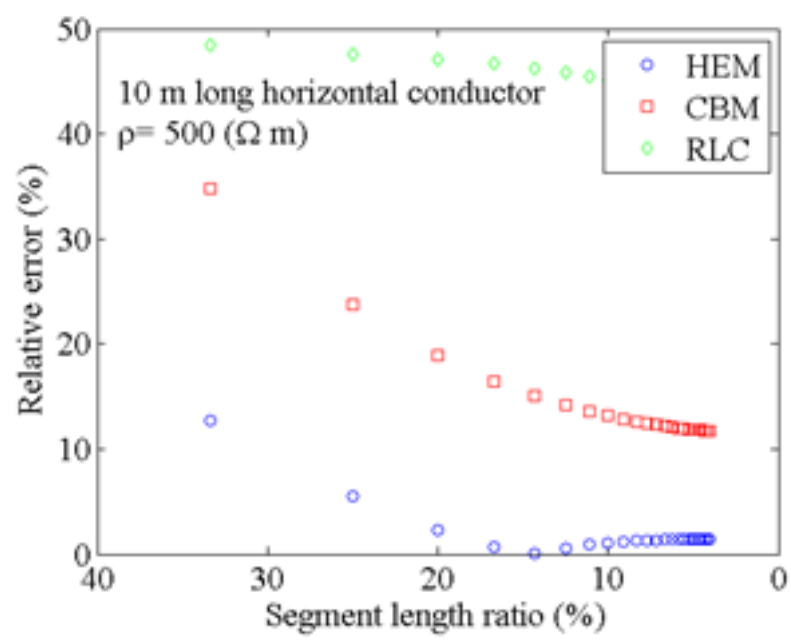

c)

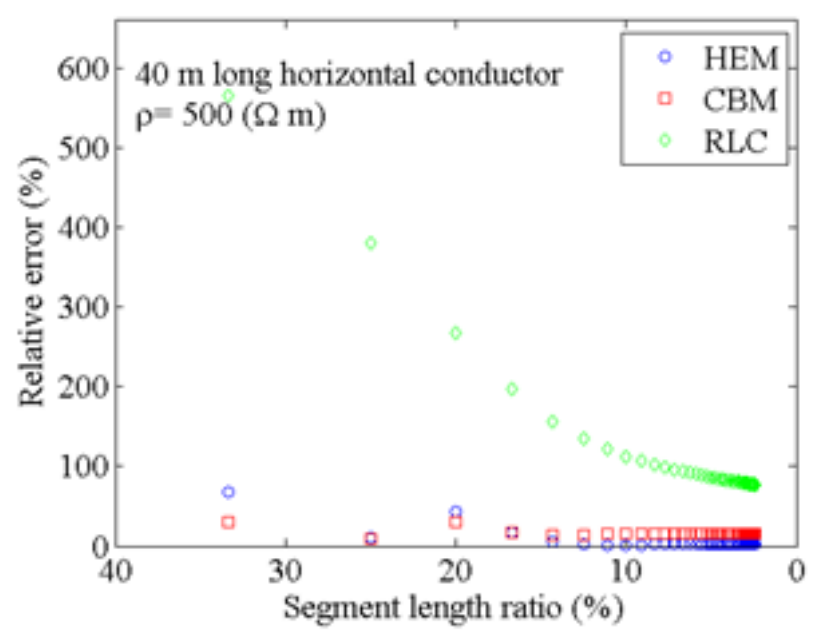

Fig. 11. Relative error in the impedance magnitude at $5 \mathrm{MHz}, \rho=500 \Omega \mathrm{m}$

\section{REFERENCES}

[1] Grčev, L. and Dawalibi, F.: An electromagnetic model for transients in grounding systems, IEEE Trans. Power Del., vol. PWRD-5, No. 4, pp. 1773-1781 (October 1990).

[2] Harrington, R. F.: Matrix methods for field problems, Proc. IEEE, vol. 55, no. 2, pp. 136-149 (Feb. 1967).

[3] Rudenberg, R.: Electrical Shock Waves in Power Systems. Cambridge, MA: Harvard Univ. Press, 1968.

[4] Dwight, H. B.: Calculation of the resistances to ground, Electr. Eng., vol. 55, pp. 1319-1328 (Dec. 1936).

[5] Sunde, E. D.: Earth Conduction Effects in Transmission Systems. 2nd ed. New York: Dover, 1968.

[6] Bourg, S., Sacepe, B., Debu, T.: Deep earth electrodes in highly resistive ground: Frequency behavior, Proc. IEEE Int. Symp. Electromagnetic Compatibility, 1995, pp. 584589.

[7] Mata, C. T., Fernandez, M. I., Rakov, V. A., Uman, M. A.: EMTP modeling of a triggered-lightning strike to the phase conductor of an overhead distribution line, IEEE Trans. Power Del., vol. 15, no. 4, pp. 1175-1181 (Oct. 2000).

[8] Shi, Z., Liu, L., Xiao, P., Geng, Z., Fang, G.: Applying transmission line theory to study the transmitting turn-off current in a long grounded wire, IEEE Trans. Antennas and Propag., vol. 65, no. 10, pp. 5112-5122 (Oct. 2017).

[9] Otero, A. F., Cidras, J., Alemo, J. L.: Frequency-dependent grounding system calculation by means of a conventional nodal analysis technique, IEEE Trans. Power Del., vol. 14, no. 3, pp. 873-878 (1999).

[10] Cidrás, J., Otero, A. F., Garrido, C.: Nodal frequency analysis of grounding systems considering the soil ionization effect, IEEE Trans. Power Del., vol. 15, no. 1, pp. 103107 (Jan., 2000).

[11] Jankoski, R., Arnautovski Toševa, V., Kacarska, M., Kuhar, A., Grčev, L.: Electric field calculation using partial element equivalent circuit and mixed potential integral equation, Proc. 5th International Symposium on Applied Electromagnetics - SAEM'2014, Ohrid, Macedonia, June 2014.

[12] Kuhar, A., Ololoska-Gagoska, L., Grčev, L.: Numerical analysis of complex grounding systems using circuit based method, 12th International Conference ETAI, Ohrid, Macedonia, September 2015.

[13] Кухар, А., Ололоска-Гагоска, Л., Грчев, Л.: Анализа на заземјувачки спроводници со користење на SPICE симулатор, 13th International Conference ETAI, Struga, Macedonia, September 2016.

[14] Kuhar, A., Grčev, L.: Contribution to calculating the impedance of grounding electrodes using circuit equivalents, FACTA UNIVERSITATIS Series: Electronics and Energetics, vol. 29, no. 4, pp. 721-732 (Dec. 2016).

[15] King, R. W. P.: Antennas in material media near boundaries with application to communication and geophysical exploration, Part I: The baremetal dipole, IEEE Trans. Antennas Propag., vol. AP-34, no. 4, pp. 483-489 (Apr. 1986).

[16] Takashima, T., Nakae, T., Ishibashi, R.: Calculation of complex fields in conducting media, IEEE Trans. Electrical Insulation, vol. EI-15, no. 1, pp. 1-7 (Feb., 1980).

[17] Visacro, S., Soares, A.: HEM: A model for simulation of lighting - Related engineering problems", IEEE Trans. Power Del., vol. 22, no. 2, pp. 1206-1208 (April 2005). 
[18] Guimarães, N. M., Araujo, L., Castro, R. V., Santos, L. F. D., Murta Vale, M. H., Visacro, S.: Impulse response of grounding grids: experimental versus simulated results, Proc. 2012 Int. Conf. Lightning Protection, Sep. 2012.

[19] Alípio, R. S., Schroeder, M. A. O., Afonso, M. M., Oliveira, T. A. S., Electromagnetic fields of buried conductors, Proc. 2008 Int. Conf. Grounding Earthing (GROUND 2008), pp. 399-402.

[20] Alípio, R. S., Schroeder, M. A. O., Afonso, M. M., Oliveira, T. A. S.: Electric fields of grounding electrodes: frequency and time domain analysis, Proc. X International Symposium on Lightning Protection, $9^{\text {th }}-13^{\text {th }}$ November, 2009 - Curitiba, Brazil.
[21] Kuhar, A., Grčev, L.: Calculating the impedance of grounding electrodes using circuit equivalents, Proc. $12^{\text {th }}$ International Conference on Applied Electromagnetics, PES2015, Niš, Serbia, September 2015.

[22] Kuhar, A., Arnautovski-Toševa, V., Grčev, L.: High frequency enhancement of the hybrid electromagnetic model by implementing complex images, Journal of Electrical Engineering and Information Technologies, 2 (2), 79-87 (2017) UDC:004.421.6:621.316.937.052.6

[23] Grčev, L., Kuhar, A., Arnautovski-Toševa, V., Markovski, B.: Evaluation of high-frequency circuit models for horizontal and vertical grounding electrodes, IEEE Trans. Power Del., 2018. http://dx.doi.org/10.1109/TPW RD.201 8.2840960 